\title{
NPPA Gene
}

National Cancer Institute

\section{Source}

National Cancer Institute. NPPA Gene. NCI Thesaurus. Code C139907.

This gene is involved in both cardiac homeostasis and pregnancy. 